\title{
Is Religiosity Related to Environmentally-Protective Behaviors Among Taiwanese Christians? A Structural Equation Modeling Study
}

\author{
Wei-Ta Fang ${ }^{1} \mathbb{D}$, Ulas Kaplan ${ }^{2, *}$, Yi-Te Chiang ${ }^{1, * \mathbb{D}}$ and Chun-Teng Cheng ${ }^{1}$ \\ 1 Graduate Institute of Environmental Education, National Taiwan Normal University, Taipei 11677, Taiwan; \\ wtfang@ntnu.edu.tw (W.-T.F.); tonygjr777@mail.naer.edu.tw (C.-T.C.) \\ 2 Human Development and Learning Program, Lesley University, Cambridge, MA 02138, USA \\ * Correspondence: ukaplan@lesley.edu (U.K.); faratajiang@gmail.com (Y.-T.C.); \\ Tel.: +1-617-349-8842 (U.K.); +886-2-7734-6558 (Y.-T.C.)
}

Received: 6 October 2020; Accepted: 26 October 2020; Published: 29 October 2020

\begin{abstract}
The objective of this study was to explore the mediators of environmental protective behaviors in Christians in Taiwan. Questionnaire data from a total of 699 participants were collected and subjected to a confirmatory factor analysis. The results revealed that the environmental behaviors of Taiwanese Christians are affected by their faith in three aspects. First, private environmental behaviors are associated with church attendance. Second, the awareness of environmental consequences generates a stewardship belief, which results in a willingness to sacrifice for the environment, private environmental behaviors, and political environmental activism. Finally, stewardship belief is also associated with political environmental activism.
\end{abstract}

Keywords: environmental education; environmental ethics; ecological theology; pro-environmental behavior

\section{Introduction}

Global weather changes and damage to the natural environment have severely threatened the survival of human beings and other species on Earth. This serious problem has provoked an awareness of environmental consequences and environmental protection behaviors among humans [1]. Since the 1960s, Christian theologians have attempted to reinstate the Bible to indicate that God, not humans, is the master of the universe [2,3]. Consequently, humans must treat everything and everybody with love, according to God's will.

White [4] indicated that the main cause of environmental damage is the Christian beliefs that have deeply affected Western civilization and thought, because Christianity is an important force that has shaped Western society, and religion can deeply affect human values and behaviors. However, many Biblical interpretations based on anthropocentrism (a human-centered worldview) exist; therefore, the Church can be considered to be a party that is responsible for modern environmental problems.

However, later theologians did not agree with White. They believed that the main cause of environmental problems is anthropocentric thought from the Renaissance period and technological innovation caused by the industrial revolution, which are sources of environmental stress. However, because of White's point, the Christian world has begun to contemplate whether the Bible contains thoughts that can respond to modern environmental problems. Christian theologists have reinterpreted the Bible to gradually develop 'ecological theology'. They have examined the environment in order to rethink the relationship among humans, God, and the universe, in order to establish new paradigms for Christian theology. 
The Bible includes emphases that human beings should treat everything with kindness. Moreover, the interpretations of modern theology involve the notion that God has bestowed upon humans the responsibility of stewardship. As is consistent with such beliefs, studies have indicated that church attendance has a positive influence on followers, demonstrating its connections with well-being $[5,6]$. However, no study has conducted a relational analysis, a confirmatory factor analysis (CFA) and structural equation modeling (SEM) on pro-environmental behaviors among Taiwanese Christians and the intervening variables affecting these behaviors. This study aimed to address this gap in the literature, and to examine the relationship between Christian religiosity and environmental behaviors. In this context, the study was guided by the following research questions:

(a) Is church attendance related to environmental behaviors [1]?

(b) Can the Christian stewardship belief be associated with becoming aware of environmental consequences, being willing to sacrifice for the environment [1], and engaging in private environmental behaviors and political environmental activism?

\section{Literature Review and Hypothesis}

The criticism proposed by White [4] resulted in the initiation of research on the relationship between Christian beliefs and pro-environmental behaviors. Since the 1980s, sociologists have analyzed the relationship between church attendance and pro-environmental behaviors among Christians. On the basis of White's viewpoints, Hand and Van Liere [7] argued that a "steward of nature" faith is formed in Christians, and that denominations that emphasize Biblical inerrancy are less concerned with environmental care than other denominations [8,9]. Therefore, Hand and Van Liere [7] insisted that no relationship exists between religion and environmental care. After the 1990s, American scholars conducted analyses using the General Social Survey (GSS), and demonstrated that there is no relationship between church attendance and green consumer behaviors [10]. Studies have also indicated no significant variation between Christianity and other religions in terms of their influence on environmental behaviors [11-18].

However, the relationship between religion and pro-environmental behaviors is considerably more complicated than the explanation provided by White [4]. In addition to the different faith emphases given by different denominations, other factors affect the generation of pro-environmental behaviors. Various pro-environmental behaviors have different affecting paths, which can be determined through SEM by adopting data from the 1993 GSS. The 1993 GSS included the variables of church attendance, the influence of stewardship belief on the understanding of environmental problems [10], and willingness to sacrifice for the environment $[10,19]$ in order to form a theoretical model based on SEM for the analysis of the relationships between private environmental behaviors and civic behaviors.

The Christian faith affects pro-environmental behaviors because Christians believe that nature is sacred [14]. According to Gardner and Stern [15], American Christians believe in the sacredness of nature, which may be connected with their personal environmental behaviors and political environmental activism. However, personal environmental behaviors do not necessarily serve as evidence that American Christians believe that "nature is sacred" because it is God's creation. This belief may even negatively affect political environmental activism [15]. We reviewed and analyzed the results of previous relevant studies, which are described in the subsequent sections.

\subsection{Church Attendance and Stewardship Belief}

Participation in church activities is a main religious activity for many Christians. Church activities include attending church, praying, and reading the Bible. Participation in church activities is the basis of Christian religious worship. According to the data from the European Social Survey of 2012, only about one-third of European Christians responded that they attended church every month. Different denominations have different forms of church meeting. Some are highly ritualistic, where the emotion of the ceremony is designed to have a spiritual impact. At the other extreme, some denominations have a simple, austere form of meeting, where members depend on the message of God's word in the bible 
for their spiritual growth. In either case, church attendance could be a valuable indicator of Christian influence. Gardner and Stern [20] were the first to conduct a path analysis on church attendance and stewardship belief. Some scholars consider that church attendance affects stewardship belief [21]. Certain scholars have held the negative view that church attendance does not affect stewardship belief, but rather affects the belief in dominion theology [22]. The belief of dominion theology emphasizes the value of human welfare, and the stewardship belief emphasizes the value of nature [23]. In recent years, ecological theology has been influential in expanding Christian thought to emphasize environmental issues [24]. Considering the aforementioned contradictory results, further exploration is required regarding whether church attendance leads to beliefs in dominionism or stewardship.

\subsection{Relationship Between The Church Attendance and Private Environmental Behaviors of Christians}

Christians participate in church services, prayer meetings and Bible readings, and receive Christian teachings. Therefore, the religious values of Christians can influence their stewardship-oriented beliefs and encourage them to engage actively in pro-environmental behaviors [1]. According to Clements et al. [25], religiosity and private environmental behaviors are positively correlated among American Christians. Moreover, the factor loading of church attendance was 0.7 for religiosity, which indicated that church attendance positively affects private environmental behaviors. Thus, church attendance prompts nonpolitical environmental protection actions.

\subsection{Stewardship Belief and Political Environmental Activism}

The concept of Earth stewardship is the root of Christian thought [26-28]. Christians believe that Genesis 1:28 in the Bible states the responsibilities that were bestowed upon humanity by God. Therefore, some Christians with a strong sense of justice believe that they must make diligent efforts in civil affairs on the basis of stewardship belief. Leary et al. [22] showed that stewardship belief affects an individual's tendency to engage in sustainable behavior. This tendency generates a devotion to civil affairs. Sherkat and Ellison [1] examined the 1993 GSS, and concluded that a sense of belonging, participation, and faith can positively influence private environmental behaviors and political environmental activism. Thus, religious participation, the superior-subordinate relationship, and Christian faith considerably influence political identification. Sherkat and Ellison [1] argued that Christians with high church attendance do not engage in intense political environmental activism. However, Christians with a strong stewardship belief may exhibit political environmental activism. Such political action, including joining environmental organizations and petitioning the government regarding environmental concerns, intensifies a person's assertions for the improvement of environmental conditions.

\subsection{Stewardship Belief and Awareness of Environmental Consequences}

As stated by Chapin et al. [28], Earth stewardship is an action-oriented measure for shaping societal and environmental pathways. Pepper and Leonard [21] claimed that the idea that "God exists in nature" is the main viewpoint of Earth stewardship expressed in Genesis 1:28. Three conclusions can be obtained from Genesis 1:28: (a) Nature is sacred because it was created by God [19,29]; (b) humans must protect the environment because it was created by God [1,19]; and (c) God exists in nature [21]. These conclusions may generate a sensitivity for nature. On the basis of the 2011 National Church Life Survey in Australia, Pepper and Leonard [21] concluded that stewardship belief positively influences Christians' understanding of environmental urgency. Thus, the lack of awareness of environmental consequences is related to weak stewardship and human activities that do not account for environmental risks [30]. Environmental hazards may result in the Earth becoming uninhabitable, and humans consequently failing to fulfill the stewardship responsibilities bestowed upon them by God.

\subsection{Awareness of Environmental Consequences and Willingness to Sacrifice for the Environment}

According to Sherkat and Ellison [1], the "awareness of environmental consequence" and "willingness to sacrifice for the environment" cause an individual to become willing to exert efforts in 
expressing concern and care for the environment. The awareness of environmental consequences can lead to an understanding of environmental urgency. Therefore, when a person attempts to invoke their awareness of environmental consequences, their willingness to sacrifice for the environment may be enhanced. Consequently, the willingness to sacrifice for the environment includes inspiring intentions that lead to a willingness to pay high taxes and prices, and to accept cuts in personal standards of living [10].

If pro-environmental behavior is a type of moral behavior, then the willingness to sacrifice for the environment is a particularly important notion from the perspectives of moral philosophy and moral psychology. The motivation to do the right thing often involves a consideration of personal costs that is demanded by certain possibilities of action, such as altruism, telling the truth, standing up for justice, and various forms of pro-environmental behaviors. Moral motivation was defined by Kaplan as a dynamic process of cognition-emotion relationships out of which moral judgment and action emerge [31]. In this process, self-interest is likely to be a major consideration. Individuals are likely to carry out the judgments and actions for which they are willing to endure the consequences of their self-interest. If the costs are higher than the individual is willing to bear, then the corresponding judgment or action is not likely to emerge.

Pro-environmental behaviors demand various sacrifices of self-interest. Individuals are more likely to carry out pro-environmental behaviors when they are willing to bear the corresponding costs to self-interest. This approach is consistent with various accounts in moral philosophy. For example, Rousseau proposed the individual's sacrifice of 'natural freedom' (based on pure self-interest) in order to attain civil freedom (based on social contract): “What man loses by the social contract is his natural freedom and an unlimited right to all that tempts him and that he can attain" [32]. Likewise, Hobbes [33] suggested that a state of living in social order is possible "in recompense of the universal right they abandon" [33]. This is a process of sacrificing a certain state, i.e., of being based in self-interest, for the sake of an interconnected civil existence. Consistently, Kant's [34] conception of 'duty as virtue' is closely connected with the sacrifices that it brings. The intrinsic moral motivation of acting from duty (rather than from personal inclination or self-interest) represents "duty as connected with the sacrifices its observance (virtue) costs us rather than with the advantages it yields us" [33]. In keeping with Kant, Kohlberg contended that "much morality involves basic sacrifice" [35].

It follows that the sacrifice of self-interest is a key dimension of pro-environmental behaviors. Consistently, Maniates and Meyer [36] proposed and examined sacrifice as the core experience for environmental sustainability, emphasizing the necessity to explore it from multiple points of view, including its important role in "religion, mythology and ritual". Maniates and Mayer also highlighted the significance of "individual action" as a common denominator of the perspectives of various contemporary scholars on environmental sustainability. In keeping with the foregoing ideas, and building on Kant's moral philosophy, we suggest that a sense of duty makes sacrifice meaningful to the individual. When these pro-environmental behaviors are carried out from a sense of duty, rather than from a desire for personal gain or social recognition, they are more likely to be sustainable. With its core emphasis on sacrifice, religious faith may be one of the possible facilitators of this sense of duty.

\subsection{Awareness of Environmental Consequences and Private Environmental Behaviors}

According to Schultz et al. [37], Christians are aware of environmental consequences because they understand environmental problems. Because of an awareness of environmental consequences, personally responsible environmental behaviors are generated [38,39]. However, Truelove and Joireman [23] argued that Christians exhibit inadequate personal environmental behaviors due to their lack of awareness or care regarding biospheric consequences. Considering the aforementioned paradoxical results, further examination is required regarding whether an awareness of environmental consequences results in positive private environmental behaviors. 


\subsection{Willingness to Sacrifice for the Environment and Private Environmental Behaviors}

The personal stewardship belief associated with self-value plays crucial roles in the formation of environmental protection attitudes and private environmental behaviors [21]. Pepper and Leonard [21] divided private environmental behaviors into 'consumer behaviors' and 'civic behaviors'. Tarakeshwar et al. [19] discovered that stewardship belief may have positive effects on environmental behaviors through the intervening variable of being "willing to sacrifice for the environment." Tarakeshwar et al. examined private environmental behaviors through four questions:

- How often do you recycle?

- How often do you volunteer time to a program?

- How often do you cut down the use of automobiles by carpooling?

- How often do you write letters to politicians on environmental issues?

\subsection{Willingness to Sacrifice for the Environment and Political Environmental Activism}

Some scholars believe that Christian individuals' willingness to sacrifice for the environment influences their political environmental activism $[1,10]$. However, other scholars believe that Christians exhibit inadequate willingness to pay for environmental protection and pro-environmental political behaviors [23]. Considering the aforementioned contradictory results, further examination is required regarding whether Christians are willing to sacrifice for the environment and engage in political environmental activism.

\subsection{Hypotheses}

Numerous studies have examined the pro-environmental behaviors of Christians in the United States since the study of White in 1967. Christianity can affect pro-environmental behaviors through intervening variables in several pathways. For example, Sherkat and Ellison [1] discovered that church attendance and stewardship belief cause the generation of civic environmental behaviors. According to the interviewees, the understanding of environmental problems [10] is an important intervening variable that directly affects private environmental behaviors and civic environmental actions through the willingness to sacrifice for the environment $[10,19]$. However, the following three hypotheses require further examination:

(a) Church attendance is associated with a positive stewardship belief [22,23].

(b) The awareness of environmental consequences is associated with positive private environmental behaviors [23].

(c) Christian individuals' willingness to sacrifice for the environment is associated with their engagement in positive political environmental activism [23].

Missionaries have visited Taiwan since the mid-19th century to spread Christianity. Including the Dutch colonial period, the history of Christianity in Taiwan is more than 300 years old. However, research has rarely been conducted on the pro-environmental behaviors of Taiwanese Christians. As such, this study was conducted on the basis of theories derived from Western countries. Although Taiwan's Christians have begun to care about the environment due to their religious beliefs, and have engaged in pro-environmental actions, insufficient fundamental theoretical bases exist to examine the relationships between Christian beliefs and pro-environmental behaviors among Taiwanese Christians.

Therefore, on the basis of a literature review of studies conducted in Western countries, we selected 'church attendance' (frequency of participation) [1,22], 'stewardship' (the intensity of faith), 'awareness of environmental consequences' (intensity of awareness), and 'willingness to sacrifice for the environment' (intensity of willingness to sacrifice) to be the variables of 'environmental behaviors'. The environmental behaviors are divided into 'private environmental behaviors' (frequency of participation) and 'political environmental activism (frequency of participation) $[1,10,21]$. 
The awareness of environmental consequences refers to being aware of the impact caused by environmental problems. The willingness to sacrifice was defined as the willingness to provide income or property to an institution. For example, the willingness to sacrifice can include the willingness of an individual to sacrifice their personal enjoyment, pay a high pollution tax or fee, or reduce their living standards. Tables 1 and 2 were compiled on the basis of previous relevant studies.

Table 1. Questions on church attendance, stewardship, the awareness of environmental consequences, and the willingness to sacrifice for the environment.

\begin{tabular}{|c|c|}
\hline \multicolumn{2}{|c|}{ Church Attendance $[1,21,22,40]$ (five-point Likert scale) } \\
\hline CA1 & How often do you participate to church activities (revised from Pepper \& Leonard [21])? \\
\hline CA2 & How often do you attend church services (worship services) [21]? \\
\hline CA3 & $\begin{array}{l}\text { How often do you spend time in devotional activities (e.g., prayer) (revised from Pepper \& } \\
\text { Leonard [21])? }\end{array}$ \\
\hline CA4 & How often do you preach Christian teachings and the Christian gospel $[1,21,40]$ ? \\
\hline \multicolumn{2}{|c|}{ Stewardship belief $[1,19,21,41]$ (five-point Likert scale) } \\
\hline S1 & Nature is sacred because it is created by God [19]. \\
\hline S2 & Human beings should respect nature because it was created by God [19]. \\
\hline S3 & I have experienced the presence of God when I have been in nature [21]. \\
\hline S4 & All life is in some form a manifestation of God [21]. \\
\hline \multicolumn{2}{|c|}{$\begin{array}{l}\text { Awareness of environmental consequences }[1,10,21] \text {. In general, do you think that [insert text below] is } \\
\text { extremely dangerous, very dangerous, somewhat dangerous, not very dangerous, or not dangerous for the } \\
\text { environment in Taiwan (revised from Dietz et al. [10])? (five-point Likert scale) }\end{array}$} \\
\hline $\mathrm{AC} 1$ & Air pollution caused by industry [10]. \\
\hline $\mathrm{AC} 2$ & Pollution of Taiwan's rivers, lakes, and streams (revised from Dietz et al. [10]). \\
\hline AC3 & Air pollution caused by cars and motorcycles (revised from Dietz et al. [10]). \\
\hline $\mathrm{AC} 4$ & $\begin{array}{l}\text { Rising sea levels as the world warms due to the greenhouse effect (revised from Dietz et al. } \\
\text { [10]; Pepper \& Leonard [21]). }\end{array}$ \\
\hline \multicolumn{2}{|c|}{$\begin{array}{l}\text { Willingness to sacrifice for the environment (How willing would you be to [insert text below] to protect } \\
\text { the environment?) }[1,10] \text { (five-point Likert scale) }\end{array}$} \\
\hline WS1 & Pay considerably high taxes [10]. \\
\hline WS2 & Pay considerably high prices [10]. \\
\hline WS3 & Accept cuts in your standard of living [10]. \\
\hline
\end{tabular}

Table 2. Questionnaire items related to private environmental behaviors and political environmental activism.

Private environmental behaviors: In the past year, I have taken the following actions to reduce environmental impact $[1,10,21]$. (five-point Likert scale)

\begin{tabular}{cl}
\hline PrB1 & Buying food products grown without pesticides or chemicals $[1,10]$. \\
\hline PrB2 & Reducing automobile use [1,10]. \\
\hline PrB3 & Refusing to eat meat for moral or environmental reasons [10]. \\
\hline
\end{tabular}

Political environmental activism $[1,10,21]$ In the past year, I have taken the following actions to reduce environmental impact. (five-point Likert scale)

\begin{tabular}{ll}
\hline PoB1 & Joining an environmental organization [1]. \\
\hline PoB2 & Signing a petition related to an environmental concern [1]. \\
\hline PoB3 & Participating in a protest or demonstration to protect the environment [21]. \\
\hline
\end{tabular}


On the basis of previously-proposed theorical models, eight hypotheses were presented in this study. For each hypothesis, each variable directly affects the subsequent variable through different pathways. Each variable may also indirectly affect the subsequent variable. We assumed that church attendance affects stewardship. Stewardship positively influences the environmental attitude, including the awareness of environmental consequences, which is influenced by the willingness to sacrifice for the environment. The willingness to sacrifice for the environment can affect private environmental behaviors and political environmental activism [1]. The previously proposed hypotheses indicate that peoples' awareness of environmental consequences leads them to believe that their actions that can mitigate environmentally disadvantageous factors.

The research model of this study comprises the following hypotheses (Figure 1):

Hypotheses 1 (H1). Church attendance positively affects stewardship [1,21].

Hypotheses 2 (H2). Church attendance positively affects private environmental behaviors [1,21].

Hypotheses 3 (H3). Stewardship positively influences political environmental activism [1,21].

Hypotheses 4 (H4). Stewardship positively influences the awareness of environmental consequences [1,21].

Hypotheses 5 (H5). The awareness of environmental consequences positively affects willingness to sacrifice for the environment $[1,10]$.

Hypotheses 6 (H6). The awareness of environmental consequences positively influences private environmental behaviors $[1,10,21])$.

Hypotheses 7 (H7). The willingness to sacrifice for the environment positively affects private environmental behaviors $[1,10]$.

Hypotheses 8 (H8). The willingness to sacrifice for the environment positively influences political environmental activism $[1,10,21]$.

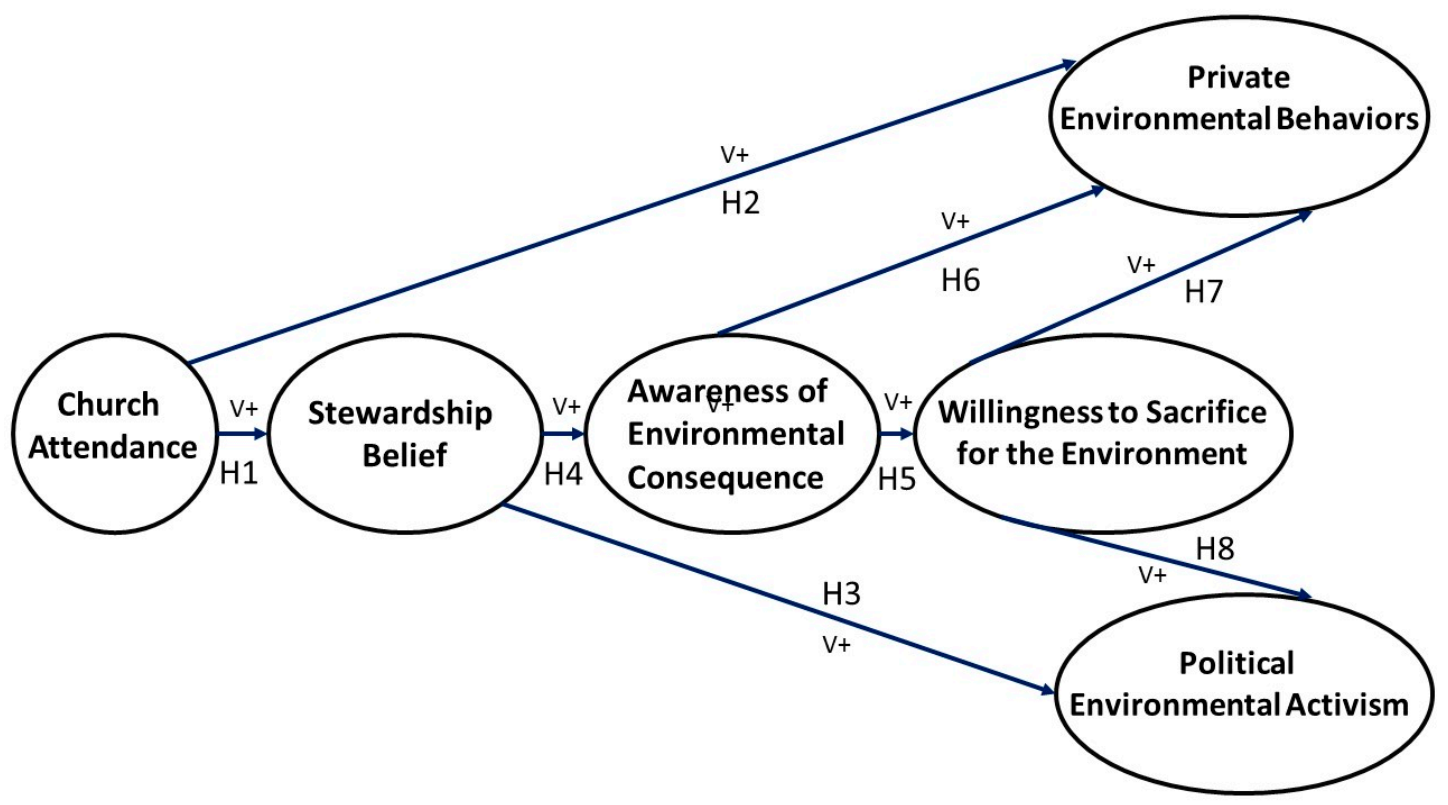

Figure 1. Hypotheses for the relationships between church attendance and environmental protective behaviors among Taiwanese Christians (i.e., stewardship belief, awareness of environmental consequences, and willingness to sacrifice for the environment). 


\section{Materials and Methods}

\subsection{Participants and Procedure}

The study involved 699 participants, who were Taiwanese Christians. According to the 2015 Taiwan Christian church trend report, 4287 churches (including those affiliated with the Seventh-day Adventist Church and True Jesus Church) operate in Taiwan. The Christian population of Taiwan aged over 5 years old comprises 1,464,981 people, accounting for $6.53 \%$ of the entire Taiwanese population. Including Catholics, Christians account for $7.62 \%$ of the Taiwanese population. An error margin of $\pm 5 \%$ is acceptable in random sampling. Therefore, 200 Taiwanese churches were contacted by telephone. A total of 1000 questionnaires were mailed to these 200 churches, which were selected through cluster sampling. The selected churches were divided by region, as follows: 94 churches in North Taiwan (Taipei City, New Taipei City, Taoyuan City, Keelung City, and Hsinchu County); 37 churches in Central Taiwan (south of Hsinchu County and north of Tainan County); 48 churches in South Taiwan (Tainan City, Kaohsiung City, and Pingtung County); and 21 churches in East Taiwan (Yilan, Hualian, and Taitung Counties). This study design was evaluated against the target population for the Christian ratio in Taiwan's four regions, i.e., $47 \%$ in North Taiwan; $18 \%$ in Central Taiwan; $24 \%$ in South Taiwan; and 11\% in East Taiwan. Five questionnaires were sent to each church in order to conduct the judgmental sampling. Between 1 August and 31 December 2016, the questionnaires were distributed to the churches and returned in postage-paid envelopes. The questionnaires were valid if they were completed by a Christian individual who was older than 18 years and had complete responses to all 21 questions.

\subsection{Measures}

As described above, we developed eight hypotheses on the basis of the previously-proposed theoretical models. The validity of these hypotheses for the questions contained in the questionnaire was examined by scholars of Christianity and environmental protection. The questionnaire was comprised of 21 questions on church attendance (CA; 4 questions), stewardship belief (S; 4 questions), the awareness of environmental consequences (AC; 4 questions), the willingness to sacrifice for the environment (WS; 4 questions), private environmental behaviors ( $\mathrm{PrB} ; 3$ questions), and political environmental activism (PoB; 3 questions). A five-point Likert scale was used to evaluate the questionnaire questions, and the methods described subsequently were used for data analysis.

SPSS 23.0 (from IBM) was used to conduct an exploratory factor analysis on the samples obtained through random sampling. The exploratory factor results confirmed the validity of the theoretical model used in this study. Descriptive statistics were determined for each observed variable, in order to understand the distribution, average value, and standard deviation of the frequency of the answered questions. LISREL 9.2 (from TStat in Europe) was used for the CFA of the samples that were not subjected to exploratory factor analysis, for the determination of the explained variance of each potential variable on each observed variable, in order to obtain a suitable measurement model. LISREL 9.2 was also used to conduct a path analysis for the verification of the proposed hypotheses and the determination of the relationship between each potential variable.

\section{Results}

\subsection{Descriptive Findings}

We distributed 1000 questionnaires to different churches. Subsequently, we followed up with the churches, starting from 1 November 2016. We sent postcard reminders and attached postage-paid envelopes to reclaim the questionnaires. A total of 711 questionnaires were received. Of the 711 received questionnaires, 699 were valid, based on which, the response rate was nearly 70\% (69.9\%). Among the 699 valid questionnaires, $213(30.5 \%)$ were answered by men, and $486(69.5 \%)$ were answered by women. The regional distribution of the study sample was as follows: 368 responses (52.6\%) were 
from North Taiwan, 153 responses (21.8\%) were from Central Taiwan, 126 responses were $(18.0 \%)$ from South Taiwan, and 52 responses (7.4\%) were from East Taiwan. The regional distribution of the research sample corresponded to that of the Christian population in Taiwan. The scores and frequencies of each question in the questionnaire are listed in Tables 3-8.

Table 3. Answer frequencies for the items relating to church attendance.

\begin{tabular}{|c|c|c|c|c|c|}
\hline \multicolumn{6}{|c|}{ Answer Frequencies (\%) for Items Related to Church Attendance (CA; Four Questions; $n=699$ ) } \\
\hline & Never & $\begin{array}{l}\text { Once in } \\
\text { a While }\end{array}$ & $\begin{array}{l}\text { 1-3 Times } \\
\text { a Month }\end{array}$ & $\begin{array}{c}\text { 1-2 Times } \\
\text { a Week }\end{array}$ & $\begin{array}{c}\text { 3-7 Times } \\
\text { a Week }\end{array}$ \\
\hline $\begin{array}{l}\text { CA1 How often do you participate to } \\
\text { church activities? }\end{array}$ & $1(0.1 \%)$ & $17(2.4 \%)$ & $39(5.6 \%)$ & $297(42.5 \%)$ & $345(49.4 \%)$ \\
\hline $\begin{array}{l}\text { CA2 How often do you attend church } \\
\text { services (worship services)? }\end{array}$ & $27(3.9 \%)$ & $138(19.7 \%)$ & $165(23.6 \%)$ & $266(38.1 \%)$ & $103(14.7 \%)$ \\
\hline $\begin{array}{l}\text { CA3 How often do you spend time in } \\
\text { devotional activities (e.g., prayer)? }\end{array}$ & $2(0.3 \%)$ & $28(4.0 \%)$ & $37(5.3 \%)$ & $100(14.3 \%)$ & $532(76.1 \%)$ \\
\hline $\begin{array}{l}\text { CA4 How often do you preach Christian } \\
\text { teachings and the Christian gospel? }\end{array}$ & $32(4.6 \%)$ & $267(38.2 \%)$ & $178(25.5 \%)$ & $146(20.9 \%)$ & $76(10.9 \%)$ \\
\hline
\end{tabular}

Table 4. Answer frequencies for items relating to stewardship belief.

\begin{tabular}{|c|c|c|c|c|c|}
\hline \multicolumn{6}{|c|}{ Answer Frequencies (\%) for Items Related to Stewardship Belief (S; Four Questions; $n=699)$} \\
\hline $\begin{array}{l}\text { S2 Human beings should respect nature because } \\
\text { it was created by God }\end{array}$ & $1(0.1 \%)$ & $1(0.1 \%)$ & $22(3.1 \%)$ & $229(32.8 \%)$ & $446(63.8 \%)$ \\
\hline $\begin{array}{l}\text { S3 I have experienced the presence of God when } \\
\text { I have been in nature }\end{array}$ & $2(0.3 \%)$ & $9(1.3 \%)$ & $58(8.3 \%)$ & $249(35.6 \%)$ & $381(54.5 \%)$ \\
\hline S4 All life is in some form a manifestation of God & $7(1.0 \%)$ & $36(5.2 \%)$ & $104(14.9 \%)$ & $303(43.3 \%)$ & $249(35.6 \%)$ \\
\hline
\end{tabular}

Table 5. Answer frequencies for the items relating to the awareness of environmental consequences.

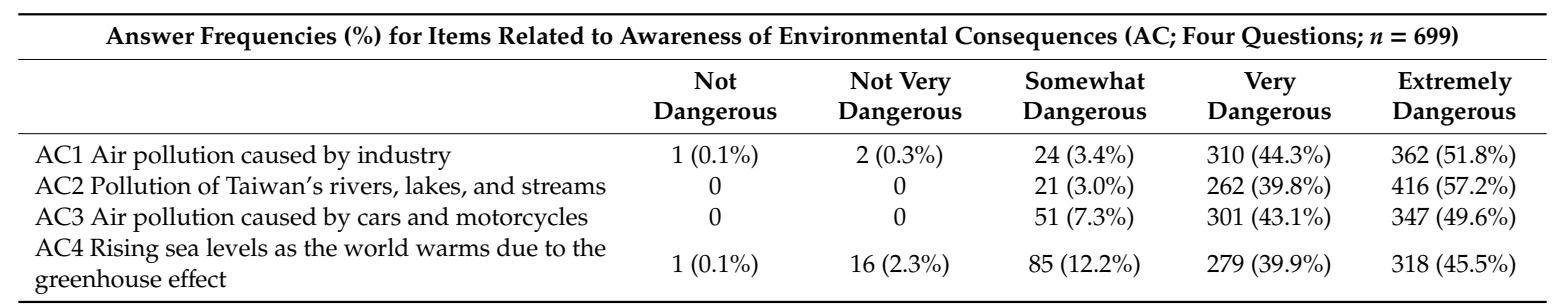

Table 6. Answer frequencies for the items relating to the willingness to sacrifice for the environment.

\begin{tabular}{|c|c|c|c|c|c|}
\hline \multicolumn{6}{|c|}{ Answer Frequencies (\%) for items Related to Willingness to Sacrifice for the Environment (WS; Three Questions; $n=699$ ) } \\
\hline & Very Unwilling & Unwilling & Average & Willing & Very Willing \\
\hline WS1 Pay considerably high taxes & $4(0.6 \%)$ & $24(3.4 \%)$ & $121(17.3 \%)$ & $411(58.8 \%)$ & $139(19.9 \%)$ \\
\hline WS2 Pay considerably high prices & $6(0.9 \%)$ & $34(4.9 \%)$ & $158(22.6 \%)$ & $375(53.6 \%)$ & $126(18.0 \%)$ \\
\hline WS3 Accept cuts in your standard of living & $8(1.1 \%)$ & $46(6.6 \%)$ & $191(27.3 \%)$ & $348(49.8 \%)$ & $106(15.2 \%)$ \\
\hline
\end{tabular}

Table 7. Answer frequencies for the items relating to private environmental behaviors.

\begin{tabular}{lccccc}
\hline \multicolumn{5}{c}{ Answer Frequencies (\%) for Items Related To Private Environmental Behaviors (PrB; Three Questions; $\boldsymbol{n = 6 9 9 )}$} \\
\hline & $\begin{array}{c}\text { Have Never } \\
\text { Done It }\end{array}$ & Sometimes & Usually & $\begin{array}{c}\text { Almost } \\
\text { Always }\end{array}$ & Always \\
\hline $\begin{array}{l}\text { PrB1 Buying food products grown } \\
\text { without pesticides or chemicals }\end{array}$ & $129(18.5)$ & $321(45.9 \%)$ & $136(19.5 \%)$ & $73(10.4 \%)$ & $40(5.7 \%)$ \\
$\begin{array}{l}\text { PrB2 Reducing automobile use } \\
\begin{array}{l}\text { PrB3 Refusing to eat meat for moral or } \\
\text { environmental reasons }\end{array}\end{array}$ & $32(4.6 \%)$ & $291(41.6 \%)$ & $134(19.2 \%)$ & $112(16.0 \%)$ & $130(18.6 \%)$ \\
\hline
\end{tabular}

Answers based on environmental behaviors in the past year. Frequency explanation: (1) Have never done it: no such behavior in the past year; (2) Sometimes: approximately 1-3 out of 10 times; (3) Usually: approximately 5 out of 10 times; (4) Almost always: approximately 8 out of 10 times; and (5) Always: 10 out of 10 times. 
Table 8. Answer frequencies for the items relating to political environmental activism.

\begin{tabular}{lccccc}
\hline \multicolumn{5}{c}{ Answer Frequencies (\%) for Items Related to Political Environmental Activism (PoB; Three Questions; $\boldsymbol{n = 6 9 9 )}$} \\
\hline & $\begin{array}{c}\text { Have Never } \\
\text { Have Done It }\end{array}$ & Sometimes & Usually & $\begin{array}{c}\text { Almost } \\
\text { Always }\end{array}$ & Always \\
\hline $\begin{array}{l}\text { PoB1 Joining an environmental organization } \\
\begin{array}{l}\text { PoB2 Signing a petition related to an } \\
\text { environmental concern }\end{array}\end{array} \quad 427(61.1 \%)$ & $154(22.0 \%)$ & $65(9.3 \%)$ & $13(1.9 \%)$ & $40(5.7 \%)$ \\
$\begin{array}{l}\text { PoB3 Participating in a protest or demonstration } \\
\text { to protect the environment }\end{array}$ & $404(57.8 \%)$ & $185(26.5 \%)$ & $62(8.9 \%)$ & $24(3.4 \%)$ & $24(3.4 \%)$ \\
\hline
\end{tabular}

Answers based on political environmental activism behavior in the past year. Frequency explanation: (1) Have never done it: no such behavior in the past year; (2) Sometimes: approximately 1-3 out of 10 times; (3) Usually: approximately 5 out of 10 times; (4) Almost always: approximately 8 out of 10 times; and (5) Always: 10 out of 10 times.

The study participants exhibited a high frequency of participation in church activities (Table 3). Approximately $49 \%$ of the study participants participated in church activities 3-7 days a week. Approximately $52 \%$ of the study participants participated in church services at least once a week and performed worship services. Thus, the study participants exhibited strong loyalty to the church. Moreover, Taiwan's Christians enjoyed self-prayer and spiritual worship. More than $76 \%$ of the study participants engaged in devotional activities (e.g., prayer) 3-7 times per week. However, the study participants did not exhibit high enthusiasm for spreading the Christian gospel. Only $32 \%$ of the participants preached Christian teachings and the Christian gospel at least once a week. A total of $4 \%$ of the participants had never preached Christian teachings or the Christian gospel.

Christians believe themselves to be God's stewards, and stewardship involves being graceful and taking responsibility. The stewardship-related items (Table 4) were "Nature is sacred because it is created by God"; "Human beings should respect nature because it was created by God"; "I have experienced the presence of God when I have been in nature"; and "All life is in some form a manifestation of God." More than half of the study participants strongly agreed with the first three items. However, only 35\% strongly agreed with the item "All life is in some form a manifestation of God." A total of $6 \%$ of the participants did not believe that all life forms are a manifestation of God; thus, these participants did not believe that the plants and animals created by God have the same right to survival as that of human beings.

The questionnaire was comprised of four items relating to the awareness of environmental consequences. The study participants exhibited a high awareness of environmental consequences (Table 5). The environmental problems that were perceived to be dangerous by the participants, in descending order, were the pollution of Taiwan's rivers, lakes, and streams (57.2\%); air pollution caused by industry (51.8\%); air pollution caused by cars and motorcycles $(49.6 \%)$; and rising sea levels as the world warms due to the greenhouse effect (45.5\%). A total of $97 \%$ of the participants believed that the pollution of Taiwan's rivers, lakes, and streams is an 'extremely dangerous' or 'very dangerous' problem. Moreover, $96 \%, 93 \%$, and $85 \%$ of the participants believed that air pollution caused by industry, air pollution caused by cars and motorcycles, and rising sea levels due to the greenhouse effect are 'extremely dangerous' or 'very dangerous' problems, respectively.

Although more than $93 \%$ of the participants perceived the aforementioned environmental problems to be very dangerous or extremely dangerous (Table 5), only $72 \%$ of the participants were willing or very willing to sacrifice for the environment. A total of $79 \%$ of the participants were willing $(58.8 \%)$ or very willing $(19.9 \%)$ to pay considerably high taxes; $72 \%$ were willing $(53.6 \%)$ or very willing $(18.0 \%)$ to pay considerably high prices; and $64 \%$ were willing ( $48.8 \%$ ) or very willing $(15.2 \%)$ to accept cuts in their standards of living.

The most frequent private environmental behavior (PrB) exhibited by the study participants was the reduction of automobile use (Table 7). A total of $18.6 \%$ of the participants always attempted to reduce their automobile use; $5.7 \%$ always bought food products grown without pesticides or chemicals; and only $0.9 \%$ always refused to eat meat for moral or environmental reasons. Thus, unlike Taiwanese 
Buddhists, Taiwanese Christians are not vegetarians for religious reasons. Only $7.4 \%$ of the study participants avoided meat in at least 5 out of 10 meals in the last year for environmental reasons. Frequent private environmental behaviors (frequencies of 'usually' (3 points on a 5-point Likert scale) or higher (4 points for 'almost always' and 5 points for 'always')) exhibited by the study participants, in descending order, were 'reducing automobile use' (53.8\%), 'buying food products grown without pesticides or chemicals' (35.6\%), and 'refusing to eat meat for moral or environmental reasons' $(7.4 \%)$.

A small proportion of the study participants engaged in political environmental activism (PoB; Table 8). A total of $5.7 \%$ of the participants 'always' joined environmental organizations; $3.4 \%$ always signed petitions related to environmental concerns; and only $0.7 \%$ always participated in protests or demonstrations to protect the environment. In descending order, the study participants frequently exhibited the following political environmental activism $(\mathrm{PoB})$ behaviors [frequency of 'usually' (points on the Likert scale) or higher (4 points for 'almost always' and 5 points for 'always')]: joining an environmental organization (16.9\%), signing a petition related to some environmental concern $(15.7 \%)$, and participating in a protest or demonstration to protect the environment $(2.4 \%)$. More than $90 \%$ of the study participants had never participated in a protest or demonstration to protect the environment. Thus, Taiwanese Christians are not enthusiastic toward political environmental activism, but are enthusiastic toward public affairs.

Table 9 displays the descriptive statistics for the 21 questions on church attendance (CA; 4 questions), stewardship belief (S; 4 questions), awareness of environmental consequences (AC; 4 questions), willingness to sacrifice for the environment (WS; 3 questions), private environmental behaviors (PrB; 3 questions), and political environmental activism (PoB; 3 questions). All of the items relating to stewardship belief and the awareness of environmental consequences had average values of more than 4 points on the 5-point Likert scale.

Table 9. Descriptive statistics for each question (minimum value, maximum value, average value, and standard deviation; $n=699$ ).

\begin{tabular}{cccccc}
\hline & Minimum Value & Maximum Value & \multicolumn{2}{c}{ Average Value } & Standard Deviation \\
\cline { 2 - 5 } & Total & Total & Total & Standard Error & Total \\
\hline CA1 & 1.0 & 5.0 & 4.385 & 0.0271 & 0.7156 \\
CA2 & 1.0 & 5.0 & 3.401 & 0.0408 & 1.0785 \\
CA3 & 1.0 & 5.0 & 4.619 & 0.0297 & 0.7856 \\
CA4 & 1.0 & 5.0 & 2.953 & 0.0416 & 1.0993 \\
S1 & 1.0 & 5.0 & 4.392 & 0.0281 & 0.7423 \\
S2 & 1.0 & 5.0 & 4.599 & 0.0217 & 0.5738 \\
S3 & 1.0 & 5.0 & 4.428 & 0.0274 & 0.7232 \\
S4 & 1.0 & 5.0 & 4.074 & 0.0338 & 0.8926 \\
AC1 & 1.0 & 5.0 & 4.474 & 0.0225 & 0.5940 \\
AC2 & 3.0 & 5.0 & 4.565 & 0.0209 & 0.5534 \\
AC3 & 3.0 & 5.0 & 4.423 & 0.0236 & 0.6250 \\
AC4 & 1.0 & 5.0 & 4.283 & 0.0293 & 0.7756 \\
WS1 & 1.0 & 5.0 & 3.940 & 0.0283 & 0.7470 \\
WS2 & 1.0 & 5.0 & 3.831 & 0.0305 & 0.8066 \\
WS3 & 1.0 & 5.0 & 3.712 & 0.0319 & 0.8423 \\
PrB1 & 1.0 & 5.0 & 2.391 & 0.0408 & 1.0775 \\
PrB2 & 1.0 & 5.0 & 3.024 & 0.0464 & 1.2268 \\
PrB3 & 1.0 & 5.0 & 1.542 & 0.0282 & 0.7451 \\
PoB1 & 1.0 & 5.0 & 1.691 & 0.0414 & 1.0952 \\
PoB2 & 1.0 & 5.0 & 1.682 & 0.0381 & 1.0068 \\
PoB3 & 1.0 & 5.0 & 1.137 & 0.0194 & 0.5118 \\
\hline
\end{tabular}

The average scores for all of the items relating to stewardship belief were higher than 4 points. The questions for the aforementioned categories, in descending order, by average score, were "Human beings should respect nature because it was created by God" (S2; $4.599 \pm 0217)$; "I have experienced the presence of God when I have been in nature" (S3; $4.428 \pm 0.0274)$; "Nature is sacred because it is created by God" (S1; $4.392 \pm 0.0281)$; and "All life is in some form a manifestation of God" (S4; $4.074 \pm$ 
0.0338). The average scores for all of the items relating to the awareness of environmental consequences were also higher than 4 points. In descending order, by average score, these items were: "pollution of Taiwan's rivers, lakes, and streams" (AC2; $4.565 \pm 0.0209)$; "air pollution caused by industry" (AC1; $4.474 \pm 0.0225$ ); "air pollution caused by cars and motorcycles" (AC3; $4.423 \pm 0.02364$ ); and "rising sea levels as the world warms due to the greenhouse effect" (AC4; $4.283 \pm 0.0293$ ).

\subsection{CFA Results}

A total of 699 samples were subjected to CFA and path analysis using LISREL 9.2. Table 10 presents the CFA results for the $\lambda$ parameter of each potential variable corresponding to each observed variable. All the $\lambda$ values are standardized. The parameter $\lambda$ explains the variance; that is, the extent to which an observed variable can reflect the changes in a potential variable. Values greater than 0.4 are acceptable for $\lambda$ [42].

Table 10. Values of $\lambda$ for Each Potential Variable.

\begin{tabular}{cccccccccccc}
\hline \multicolumn{2}{c}{ CA } & \multicolumn{2}{c}{ S } & \multicolumn{2}{c}{ AC } & \multicolumn{2}{c}{ WS } & \multicolumn{2}{c}{ PrB } & PoB \\
\hline CA1 & $0.77^{* *}$ & S1 & $0.86^{* * *}$ & AC1 & $0.73^{* * *}$ & WS1 & $0.84^{* * *}$ & PrB1 & $0.82^{* * *}$ & PoB1 & $0.64^{* * *}$ \\
CA2 & $0.68^{* * *}$ & S2 & $0.81^{* * *}$ & AC2 & $0.84^{* * *}$ & WS2 & $0.53^{* * *}$ & PrB2 & $0.94^{* * *}$ & PoB2 & $0.23^{* * *}$ \\
CA3 & $0.56^{* * *}$ & S3 & $0.69^{* * *}$ & AC3 & $0.59^{* * *}$ & WS3 & $0.42^{* * *}$ & PrB3 & $0.41^{* * *}$ & PoB3 & $0.38^{* * *}$ \\
CA4 & $0.55^{* * *}$ & & $0.67^{* * *}$ & AC4 & $0.39^{* * *}$ & & & & & & \\
\hline
\end{tabular}

All of the $\lambda$ values are standardized; ${ }^{*}, t$ value $=1.96(p<0.05) ;{ }^{* *}, t$ value $=2.58(p<0.01) ;{ }^{* * *}, 3.29(p<0.001)$.

The designed model's Chi-square $=406.55$; degrees of freedom $=181$; its $p$ value $=0.000(<0.005)$; root mean square error of the approximation of the model's goodness-of-fit index $(\mathrm{GFI})=0.043(<0.08)$; non-normed fit index $=0.929(>0.9)$; comparative fit index $=0.939(>0.9)$; and GFI $=0.946(>0.9)$. All of the aforementioned results comply with the standard.

\subsection{Hypothesis Testing}

H1 states that church attendance positively affects stewardship belief. The path $\gamma$ value of H1 was 0.03 , its $t$ value was 0.64 , and its $p$ value was $>0.05$; thus, the path of $\mathrm{H} 1$ was nonsignificant. Consequently, $\mathrm{H} 1$ is not supported. $\mathrm{H} 2$ states that church attendance positively affects private environmental behaviors. The path $\gamma$ value of $\mathrm{H} 2$ was 0.11 , its $t$ value was 2.46 , and its $p$ value was $<0.01$; thus, the path of $\mathrm{H} 2$ reached significance. Consequently, $\mathrm{H} 2$ is supported. $\mathrm{H} 3$ states that stewardship belief positively affects political environmental activism. The path $\beta$ value of $\mathrm{H} 3$ was 0.24 , its $t$ value was 4.02 , and its $p$ value was $<0.001$; thus, the path of $\mathrm{H} 3$ reached significance. Consequently, $\mathrm{H} 3$ is supported. $\mathrm{H} 4$ states that stewardship belief positively affects the awareness of environmental consequences. The path $\beta$ value of $\mathrm{H} 4$ was 0.40 , its $t$ value was 8.50 , and its $p$ value was $<0.001$; thus, the path of $\mathrm{H} 4$ reached significance, and $\mathrm{H} 4$ is supported. $\mathrm{H} 5$ states that the awareness of environmental consequences positively influences the willingness to sacrifice for the environment. The path $\beta$ value of $\mathrm{H} 5$ was 0.15 , its $t$ value was 2.48, and its $p$ value was $<0.05$; thus, the path of $\mathrm{H} 5$ reached significance. Consequently, $\mathrm{H} 5$ is supported. $\mathrm{H} 6$ states that the awareness of environmental consequences positively affects private environmental behaviors. The path $\beta$ value of $\mathrm{H} 6$ was 0.04 , its $t$ value was 0.91 , and its $p$ value was $>0.05$; thus, the path of $\mathrm{H} 6$ did not reach significance, and $\mathrm{H} 6$ is not supported. $\mathrm{H7}$ states that the willingness to sacrifice for the environment positively affects private environmental behaviors. The path $\beta$ value of $\mathrm{H7}$ was 0.14 , its $t$ value was 2.94 , and its $p$ value was $<0.05$; thus, the path of $\mathrm{H} 7$ reached significance, and $\mathrm{H} 7$ is supported. $\mathrm{H} 8$ states that the willingness to sacrifice for the environment positively influences political environmental activism. The path $\beta$ value of $\mathrm{H} 8$ was 0.40 , its $t$ value was 5.26 , and its $p$ value was $<0.001$; thus, the path of $\mathrm{H} 8$ reached significance, and $\mathrm{H} 8$ is supported. These findings are summarized in Table 11, followed by a path diagram of possible relations between Church attendance and pro-environmental behaviors in Figure 2. 
Table 11. Hypothesis verification.

\begin{tabular}{|c|c|c|c|}
\hline & Hypothesis & Significance & Verification \\
\hline H1 & Church attendance positively affects stewardship belief & & Not supported \\
\hline $\mathrm{H} 2$ & Church attendance positively affects private environmental behaviors & ** & supported \\
\hline H3 & Stewardship belief positively affects political environmental activism & $* * *$ & supported \\
\hline $\mathrm{H} 4$ & Stewardship belief positively affects awareness of environmental consequences & $* * *$ & supported \\
\hline H5 & $\begin{array}{l}\text { Awareness of environmental consequences positively affects willingness to } \\
\text { sacrifice for the environment }\end{array}$ & * & supported \\
\hline H6 & $\begin{array}{l}\text { Awareness of environmental consequences positively affects private } \\
\text { environmental behaviors }\end{array}$ & & Not supported \\
\hline H7 & $\begin{array}{l}\text { Willingness to sacrifice for the environment positively affects private } \\
\text { environmental behaviors }\end{array}$ & ** & supported \\
\hline H8 & $\begin{array}{l}\text { Willingness to sacrifice for the environment positively affects political } \\
\text { environmental activism }\end{array}$ & $* * *$ & supported \\
\hline
\end{tabular}

Two-tailed test; ${ }^{*} p<0.05,{ }^{* *} p<0.01,{ }^{* * *} p<0.001$

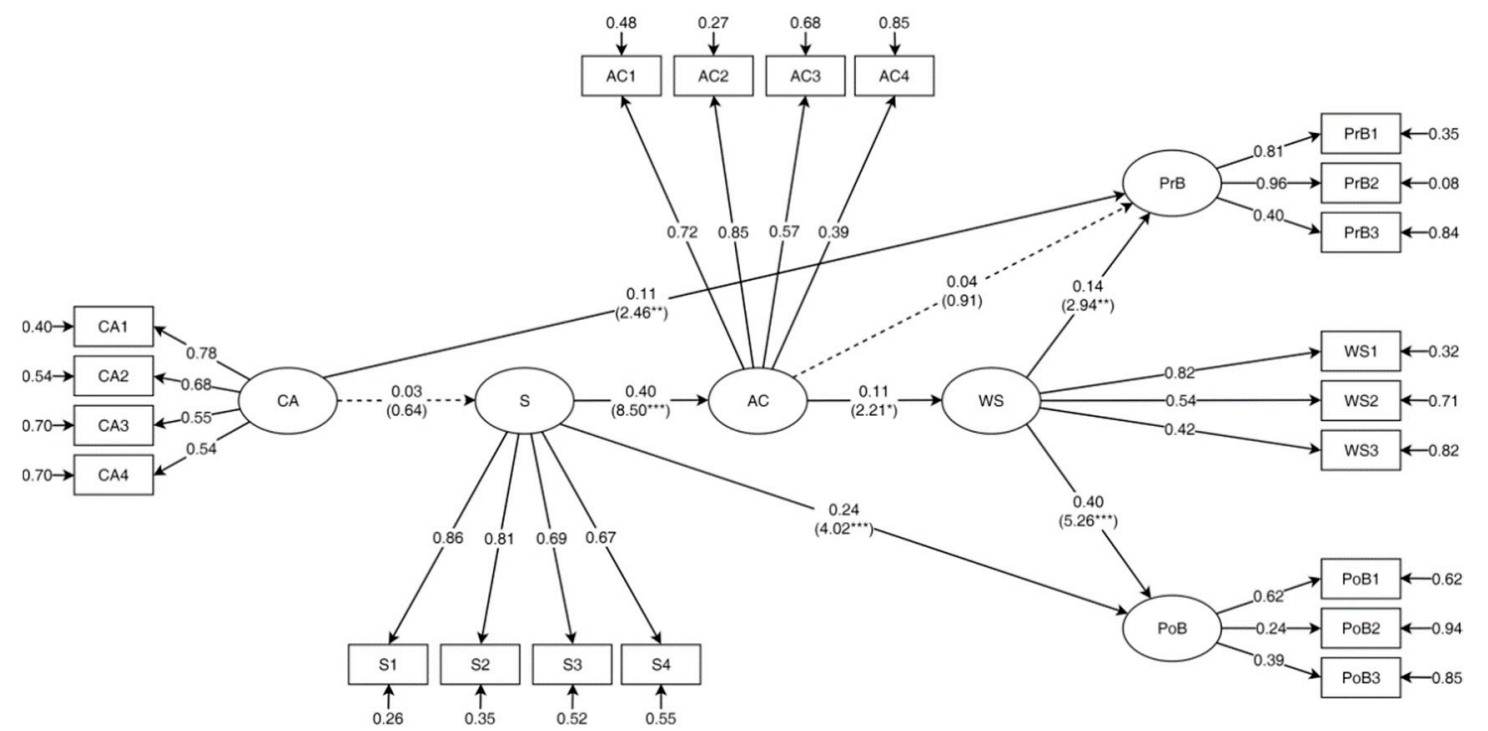

Chi-Square $=411.90, \mathrm{df}=181, \mathrm{P}$-value $=0.00000, \mathrm{RMSEA}=0.043$

Figure 2. Path diagram of the relationships between church attendance (CA) and environmental protective behaviors exhibited by Taiwanese Christians (i.e., stewardship belief (S), awareness of environmental consequences (AC), and willingness to sacrifice for the environment (WS)).

The results of this research indicate that the church attendance of Taiwanese Christians does not affect their stewardship belief. This finding contradicts those obtained in Western countries. Stewardship belief directly influences the awareness of environmental consequences. Moreover, it affects the willingness to sacrifice for the environment (WS) through the awareness of environmental consequences. Thus, the awareness of environmental consequences is an intervening variable between stewardship belief and the willingness to sacrifice for the environment. The awareness of environmental consequences directly influences the willingness to sacrifice for the environment. Moreover, it influences political environmental activism through the willingness to sacrifice for the environment. Thus, the willingness to sacrifice for the environment is an intervening variable between stewardship belief and political environmental activism. The willingness to sacrifice for the environment and stewardship belief directly affect political environmental activism.

Church attendance and the willingness to sacrifice for the environment directly influence private environmental behaviors. However, the awareness of environmental consequences and stewardship belief do not directly affect private environmental behaviors. 


\section{Discussion}

Some of the results of this study are consistent with those of similar studies conducted in Western countries; however, certain results were unique to this study, possibly because of the condition of Taiwanese society, the historical context of the development of Christianity in Taiwan, or the limitations of the research method. We examined (a) the generation path of the unique worldview of Taiwanese Christians on stewardship belief, (b) the influence of church attendance on private environmental behaviors, (c) the influence of stewardship belief on the awareness of environmental consequences, and (d) the influence of the willingness to sacrifice for the environment on private environmental behaviors and political environmental activism.

\subsection{Generation Path of the Unique Worldview of Taiwanese Christians on Stewardship Belief}

The average scores for the four items related to stewardship belief were greater than 4 points. Approximately $80-90 \%$ of the study participants provided scores of 4 or 5 for the aforementioned items. Thus, most Taiwanese Christians identify with the stewardship belief. Consequently, we must examine the effect of stewardship belief on the environmental behaviors of Taiwanese Christians, and determine the variables through which these behaviors are generated. The worldview of stewardship belief originates from the Bible, but is not correlated with church attendance in Taiwan. This result differs from the results obtained in similar studies conducted among American and Australian Christians.

In the studies of Sherkat and Ellison [1] and Pepper and Leonard [21], church attendance positively affected stewardship belief. The stronger the devotion to the Christian faith, the more frequent participation was in church activities and services, and the more influence the faith had. Thus, strong devotion to the Christian faith results in the formation of a unique worldview based on this faith. However, these results are not observed in Taiwan. A reason for this result may be Taiwanese peoples' generally friendly attitude toward the environment, which affects the worldview formation of religious people independently of church attendance. A series of environmental protection movements have occurred in Taiwan since the 1970s. Taipei City promotes resource recycling. In 2011, the Environmental Education Act was passed in Taiwan. In the context of environmental education, respecting nature and protecting the environment have become basic values recognized by all of the people. According to Cobern [43], a worldview is formed in an individual's subconscious. Therefore, because Taiwanese people are commonly environmentally conscious, Taiwanese Christians tend to internalize the environment affinity worldview, and not the human-centric belief criticized by White [4].

When nearly all people believe that the worldview of stewardship belief is correct, those who do not attend church services often would not be affected. However, in the United States, church denominations influence the faith worldview formation of their followers. Environmental behaviors differ significantly among fundamentalist and evangelical churches in the United States. Major differences among fundamentalist, evangelical, and free church denominations lie in the interpretation of Biblical inerrancy. Fundamentalists believe that the words in the Bible cannot be changed, and that God is absolute. These beliefs are reflected in the behavior of fundamentalists. They do not easily accept new viewpoints, and lean toward political conservativism. Thus, the beliefs of fundamentalists negatively affect their environmental behaviors. The views of the evangelical churches are between those of fundamentalist and liberal Christianity. The evangelicals also believe that the words of the Bible cannot be changed at will; however, this faction is more open to modern viewpoints than fundamentalists are. Evangelical Christians are not as conservative as fundamentalists are. In the 1990s, the evangelical denominations initiated many 'green' movements in the United States [44]; thus, the relationship between evangelicals and environmental behaviors is positive.

Many church denominations operate in Taiwan. All of the denominations of the New Christian Church, except the Presbyterian Church, entered Taiwan only after 1949, when the Kuomintang government moved to Taiwan. According to the documentation, unlike the denominations in the United States, no significant differences exist among Christian denominations in Taiwan in terms of Biblical inerrancy. Moreover, no significant difference exists between the 'free' and 'conservative' 
denominations. The descriptive statistics indicate that approximately $80-90 \%$ of the study participants (from the different church denominations) provided high scores for the items relating to stewardship belief. Thus, it is possible that the formation of the worldview of stewardship belief in Taiwan originates from the cultural background, education system and policies of Taiwan, rather than originating from the teachings of the churches or church attendance.

\subsection{Influence of Church Attendance Among Taiwanese Christians on Their Private Environmental Behaviors}

In the research model, the factors and paths affecting 'private environmental behaviors' and 'political environmental activism' differ. According to Djupe and Hunt [45], church attendance directly influences private environmental behaviors by producing a pro-environmental attitude. Information transmission among church members is more important than piety and church teachings are. Thus, church attendance does not directly result in the formation of a worldview. Rather, the interactions, connections, and information transmission performed through social networks result in behavioral changes.

\subsection{Influence of Stewardship Beliefs Among Taiwanese Christians on Their Awareness of Environmental Consequences}

The environmental stewardship beliefs of Taiwanese Christians have two aspects. The first aspect involves the protection of the environment because of its importance. The second aspect involves protecting the environment because of its link with care for people. The awareness of environmental consequences is an intervening variable between the stewardship belief and worldview-induced environmental protection behaviors of Taiwanese Christians.

Similar to the results of Sherkat and Ellison [1], the awareness of environmental consequences was found to be an important intervening variable between religion and the environment in this study. Sensing the severity of the problems in the surrounding environment and inducing environmental actions through different variables are convenient measures for caring for nature.

When Christians understand more regarding the consequences of environmental problems for nature, themselves, other human beings, and the next generation, they are more likely to engage in environmental action. Sacrificing oneself to love others and easing the hardships of others are the core teachings of Christianity. Taiwanese Christians care deeply for those experiencing hardship, and provide considerable assistance to those who require it. However, it is questionable whether this care extends to the environment. Moreover, environmental problems are accompanied by injustice at the regional, national, and global levels, and cause people in some regions to be affected by hardship and poverty. If environmental problems and injustices are connected, an important bridge would be established that would prompt the church to be devoted to environmental protection.

\subsection{Influence of Taiwanese Christians' Willingness to Sacrifice for the Environment on Their Private Environmental Behaviors and Political Environmental Activism}

The awareness of environmental consequences is an important intervening variable between the religious worldview and environmentally-protective actions. However, the awareness of environmental consequences does not directly induce environmentally-protective actions. Studies have determined that the awareness of environmental consequences induces private environmental behaviors; however, this result was not obtained in the present study. In this study, the willingness to sacrifice for the environment influences private environmental behaviors and political environmental activism. According to the path analysis results, the willingness to sacrifice for the environment is an intervening variable between the awareness of environmental consequences and political environmental activism. The willingness to sacrifice for the environment induces political environmental activism only when the awareness exists regarding the severity of environmental consequences. Therefore, the awareness of environmental consequences results in the willingness to sacrifice for the environment, which induces environmentally-protective actions. 


\section{Conclusion, Limitations, and Future Research}

According to the study results, among Taiwanese Christians, stewardship belief induces an awareness of environmental consequences and a willingness to sacrifice for the environment, which further induces private environmental behaviors and political environmental activism. The development of a Christian environmental education program based on the study results would effectively encourage Taiwanese Christians to engage in environmental action. The aforementioned objective is the ultimate goal of environmental education, namely, the cultivation of responsible citizens for environmental actions.

Because no studies similar to the present study have been conducted in Taiwan, we could only develop a behavior model that can analyze six variables; however, additional factors influence private environmental behaviors and political environmental activism. If previous relevant Western studies are considered, environmental responsibility and internal control view variables can be used to generate additional paths that can better indicate the degree of influence among the considered factors. Thus, future studies can extend this research by including other factors that may influence environmental actions.

The worldview of stewardship belief does not directly influence the willingness to sacrifice for the environment. The core tenets of Christianity are love and sacrifice. However, the aforementioned variables did not directly influence each other in this study, because the items on the willingness to sacrifice for the environment were related to the reduction of one's living standards and the payment of high prices for the environment, which are marginally different from the concept of sacrifice in Christianity. The sacrifice examined in this study focused on the environment. Therefore, when individuals are aware of environmental consequences, they would be willing to sacrifice for the environment. If the Christian concept of sacrifice is incorporated into questionnaire items to form a new 'willingness to sacrifice' aspect, the path discovered may differ from the results of this study. Thus, if future researchers revise the 'willingness to sacrifice for the environment' variable to include faith questions, different results from those of this study may be obtained.

An important limitation of the present study is the use of the correlational method. Inferences about possible influences on pro-environmental behaviors must be viewed as assumptions that need further examination. Time-series data representing individuals' activity over time can be useful toward understanding and explaining the complex processes by which pro-environmental behaviors emerge and develop through the influence of multiple factors, which themselves are likely to change dynamically. Furthermore, it is likely that many of the influences that are modeled in this study are likely to be reciprocal, rather than one-directional. More complex models that account for bi-directional influences over time are more likely to shed light on the real-life development of pro-environmental behaviors.

The results of this study were consistent with those of Sherkat and Ellison [1] and Pepper and Leonard [21]. Furthermore, the results of this study are unique to Taiwan, and are related to Taiwanese Christian culture, policy, education, and society. The Church provides many teachings on the spirit of sacrifice and the life of Jesus. It emphasizes caring for fellow humans. However, the Church rarely spearheads environmental protection actions, because the followers of the Church do not link environmental problems with human care. Environmental problems not only cause damage to the environment but also result in injustice. The Church in Taiwan remains in the initial stages of obtaining and spreading knowledge on this link between environmental degradation and injustice through ecological theology. Furthermore, cultural factors have not been directly examined in this study. As such, we suggest that future studies be conducted in order to explore the potential influence of cultural factors on Christian belief, and its connection to pro-environmental behaviors.

Author Contributions: W.-T.F., C.-T.C. and Y.-T.C. conceived and designed the experiments; C.-T.C. and Y.-T.C. performed the experiments; C.-T.C. and Y.-T.C. analyzed the data; W.-T.F., and Y.-T.C. contributed the analysis tools; W.-T.F., U.K., Y.-T.C., and C.-T.C. wrote the paper. All authors have read and agreed to the published version of the manuscript.

Funding: This research was supported by grants from the Ministry of Science and Technology (109-2511-H-003 -031 to W.-T. Fang). This article was also subsidized by the National Taiwan Normal University (NTNU), Taiwan. 
Acknowledgments: We thank the members of the Graduate Institute of Environmental Education, National Taiwan Normal University (NTNU), for their contributions to the manuscript. Useful suggestions from two anonymous reviewers were incorporated into the manuscript.

Conflicts of Interest: The authors declare no conflict of interest.

\section{References}

1. Sherkat, D.E.; Ellison, C.G. Structuring the Religion-Environment Connection: Identifying Religious Influences on Environmental Concern and Activism. J. Sci. Study Relig. 2007, 46, 71-85. [CrossRef]

2. Santmire, H.P. The Travail of Nature: The Ambiguous Ecological Promise of Christian Theology; Fortress Press: Minneapolis, MN, USA, 1985.

3. Cobb, J.B. Is It too Late? A Theology of Ecology; Environmental Ethics Books: Denton, TX, USA, 1995.

4. White, L. The Historical Roots of Our Ecologic Crisis. Science 1967, 155, 1203-1207. [CrossRef]

5. Ellison, C.G.; Boardman, J.D.; Williams, D.R.; Jackson, J.S. Religious Involvement, Stress, and Mental Health: Findings from the 1995 Detroit Area Study. Soc. Forces 2001, 80, 215-249. [CrossRef]

6. Leondari, A.; Gialamas, V. Religiosity and psychological well-being. Int. J. Psychol. 2009, 44, 241-248. [CrossRef]

7. Hand, C.M.; Van Liere, K.D. Religion, Mastery-Over-Nature, and Environmental Concern. Soc. Forces 1984, 63, 555-570. [CrossRef]

8. Shaiko, R.G. Religion, politics, and environmental concern: A powerful mix of passions. Soc. Sci. Q. 1987, 68, 244.

9. Eckberg, D.L.; Blocker, T.J. Varieties of Religious Involvement and Environmental Concerns: Testing the Lynn White Thesis. J. Sci. Study Relig. 1989, 28, 509. [CrossRef]

10. Dietz, T.; Stern, P.C.; Guagnano, G.A. Social Structural and Social Psychological Bases of Environmental Concern. Environ. Behav. 1998, 30, 450-471. [CrossRef]

11. Greeley, A. Religion and Attitudes toward the Environment. J. Sci. Study Relig. 1993, 32, 19. [CrossRef]

12. Woodrum, E.; Hoban, T. Theology and Religiosity Effects on Environmentalism. Rev. Relig. Res. 1994, 35, 193. [CrossRef]

13. Kanagy, C.L.; Nelsen, H.M. Religion and Environmental Concern: Challenging the Dominant Assumptions. Rev. Relig. Res. 1995, 37, 33. [CrossRef]

14. Wolkomir, M.; Futreal, M.; Woodrum, E.; Hoban, T. Substantive religious belief and environmentalism. Soc. Sci. Q. 1997, 78, 96-108.

15. Hayes, M.M.B.C.; Hayes, B.G.; Marangudakis, M. Religion and attitudes towards nature in Britain. Br. J. Sociol. 2001, 52, 139-155. [CrossRef]

16. Gifford, E.; Galante, J.; Kaji, A.H.; Nguyen, V.; Nelson, M.T.; Sidwell, R.A.; Hartranft, T.; Jarman, B.; Melcher, M.; Reeves, M.; et al. Factors Associated With General Surgery Residents' Desire to Leave Residency Programs. JAMA Surg. 2014, 149, 948-953. [CrossRef]

17. Maibach, E.W.; Leiserowitz, A.; Roser-Renouf, C.; Mertz, C.K. Identifying Like-Minded Audiences for Global Warming Public Engagement Campaigns: An Audience Segmentation Analysis and Tool Development. PLoS ONE 2011, 6, e17571. [CrossRef]

18. Morrison, M.; Duncan, R.; Parton, K. Religion Does Matter for Climate Change Attitudes and Behavior. PLOS ONE 2015, 10, e0134868. [CrossRef]

19. Tarakeshwar, N.; Swank, A.B.; Pargament, K.I.; Mahoney, A. The Sanctification of Nature and Theological Conservatism: A Study of Opposing Religious Correlates of Environmentalism. Rev. Relig. Res. 2001, $42,387$. [CrossRef]

20. Gardner, G.T.; Stern, P.C. Environmental Problems and Human Behavior; Pearson Custom Publishing: Boston, MA, USA, 2002.

21. Pepper, M.; Leonard, R. How Ecotheological Beliefs Vary Among Australian Churchgoers and Consequences for Environmental Attitudes and Behaviors. Rev. Relig. Res. 2015, 58, 101-124. [CrossRef]

22. Leary, R.B.; Minton, E.A.; Mittelstaedt, J.D. Thou Shall Not? The Influence of Religion on Beliefs of Stewardship and Dominion, Sustainable Behaviors, and Marketing Systems. J. Macromarketing 2016, 36, 457-470. [CrossRef]

23. Truelove, H.B.; Joireman, J. Understanding the Relationship between Christian Orthodoxy and Environmentalism. Environ. Behav. 2009, 41, 806-820. [CrossRef] 
24. Reichert, A. Sacred Trees, Sacred Deer, Sacred Duty to Protect: Exploring Relationships between Humans and Nonhumans in the Bishnoi Community. Ph.D. Thesis, Université d'Ottawa/University of Ottawa, Ottawa, ON, USA, 2015.

25. Clements, J.M.; McCright, A.M.; Xiao, C. Green Christians? An Empirical Examination of Environmental Concern within the U.S. General Public. Organ. Environ. 2013, 27, 85-102. [CrossRef]

26. Conradie, E.M. Christianity and Ecological Theology: Resources for Further Research; African Sun Media: Stellenbosch, South Africa, 2006.

27. Kearns, L.; Keller, C. Ecospirit: Religions and Philosophies for the Earth; Fordham Univ Press: New York, NY, USA, 2009.

28. Chapin, F.S.; Pickett, S.T.A.; Power, M.E.; Jackson, R.B.; Carter, D.M.; Duke, C. Earth stewardship: A strategy for social-ecological transformation to reverse planetary degradation. J. Environ. Stud. Sci. 2011, 1, 44-53. [CrossRef]

29. Farrell, J. Environmental Activism and Moral Schemas. Environ. Behav. 2011, 45, 399-423. [CrossRef]

30. García-Martín, M.; Plieninger, T.; Bieling, C. Dimensions of Landscape Stewardship across Europe: Landscape Values, Place Attachment, Awareness, and Personal Responsibility. Sustainability 2018, 10, 263. [CrossRef]

31. Kaplan, U. Moral Motivation as a Dynamic Developmental Process: Toward an Integrative Synthesis. J. Theory Soc. Behav. 2016, 47, 195-221. [CrossRef]

32. Rousseau, J.J. Of the Social Contract. Or Principles of Political Right; Original work published 1762; King's Court Communications: Brunswick, OH, USA, 1978.

33. Hobbes, T. Leviathan. or, the Matter, Forme, E Power of a Common-Wealth Ecclesiasticall and Civill; Andrew Crooke: London, UK, 1651.

34. Kant, I. Practical philosophy. In The Cambridge Edition of the Works of Immanuel Kant; Original works published 1783 through 1798; Gregor, M.J., Ed.; Cambridge University Press: Cambridge, UK, 1996.

35. Kohlberg, L. From is to ought: How to commit the naturalistic fallacy and get away with it in the study of moral development. In Cognitive Development and Epistemology; Mischel, T., Ed.; Academic Press: New York, NY, USA, 1971; pp. 151-235.

36. Maniates, M.; Meyer, J.M. The Environmental Politics of Sacrifice; The MIT Press: Cambridge, UK, 2010.

37. Schultz, P.W.; Zelezny, L.; Dalrymple, N.J. A Multinational Perspective on the Relation between Judeo-Christian Religious Beliefs and Attitudes of Environmental Concern. Environ. Behav. 2000, 32, 576-591. [CrossRef]

38. Stern, P.C.; Dietz, T.; Kalof, L. Value Orientations, Gender, and Environmental Concern. Environ. Behav. 1993, 25, 322-348. [CrossRef]

39. Stern, P.C.; Kalof, L.; Dietz, T.; Guagnano, G.A. Values, Beliefs, and Proenvironmental Action: Attitude Formation Toward Emergent Attitude Objects1. J. Appl. Soc. Psychol. 1995, 25, 1611-1636. [CrossRef]

40. Azzi, C.; Ehrenberg, R. Household Allocation of Time and Church Attendance. J. Political Econ. 1975, 83, 27-56. [CrossRef]

41. Dunlap, R.E.; Van Liere, K.D.; Mertig, A.G.; Jones, R.E. New Trends in Measuring Environmental Attitudes: Measuring Endorsement of the New Ecological Paradigm: A Revised NEP Scale. J. Soc. Issues 2000, 56, 425-442. [CrossRef]

42. Pett, M.; Lackey, N.; Sullivan, J. Making Sense of Factor Analysis; SAGE Publications: Thousand Oaks, CA, USA, 2003.

43. Cobern, W.W. World View Theory and Science Education Research: Fundamental Epistemological Structure as a Critical Factor in Science Learning and Attitude Development. In Proceedings of the Annual Meeting of the National Association for Research in Science Teaching, San Francisco, CA, USA, March 1989.

44. Clements, J.M.; Xiao, C.; McCright, A.M. An Examination of the "Greening of Christianity" Thesis Among Americans, 1993-2010. J. Sci. Study Relig. 2014, 53, 373-391. [CrossRef]

45. Djupe, P.A.; Hunt, P.K. Beyond the Lynn White Thesis: Congregational Effects on Environmental Concern. J. Sci. Study Relig. 2009, 48, 670-686. [CrossRef]

Publisher's Note: MDPI stays neutral with regard to jurisdictional claims in published maps and institutional affiliations. 